\title{
Pediatric hypereosinophilia: FIP1L1-PDGFRA myeloproliferative disease in a 14-year-old male
}

\author{
Shiqi S Wang, Rachel K Conyers* \\ Children's Cancer Centre, Royal Children's Hospital, Melbourne, Australia
}

Received: March 10, 2016

DOI: $10.5430 /$ crim.v3n2p41
Accepted: March 28, 2016

Online Published: May 5, 2016

\begin{abstract}
Hypereosinophilic myeloproliferative disease is a rare entity in the pediatric population. We report the fifth known pediatric case of FIP1L1-PDFGRA hypereosinophilia. This fusion drives hypereosinophilia, and often neutrophilia, with the propensity for T-cell or myeloid transformation. The exquisite sensitivity of the FIP1L1-PDGFRA fusion to the tyrosine kinase inhibitor Imatinib, abrogates the short-term life threatening complications of hyper-eosinophilia. The issues arising from long-term treatment with Imatinib, including optimal dosing, length of treatment, and bone marrow transplantation, are explored in the accompanying discussion. These issues are particularly relevant in pediatric patients facing life-long therapy.
\end{abstract}

Key Words: Hypereosinophilia, FIP1L1-PDGFRA, Pediatric hematology/Oncology, Lmatinib

\section{INTRODUCTION}

The hypereosinophilic syndromes, first described by Chusid et al. in $1970 \mathrm{~s},{ }^{[1]}$ comprise a heterogeneous group of nonhematologic (secondary or reactive) and hematologic (primary or clonal) diseases. The diagnosis is united by a persistently elevated eosinophil count of greater than $1,500 / \mathrm{mm}^{3}$, and resultant end-organ damage from eosinophilic tissue infiltration. Hypereosinophilia contributes to significant morbidity and mortality, with frequently reported causes of death from progressive cardiac disease, thromboembolic phenomena, neurologic dysfunction, and infection. ${ }^{[2]}$

Treatment for secondary eosinophilia focuses upon treating the underlying disease process; in contrast, treatment of primary/clonal hypereosinophilia historically has been limited to corticosteroids and cytotoxic agents, e.g. hydroxyurea, with profoundly disappointing high mortality and morbidity rates. ${ }^{[1]}$ The discovery of the fusion protein FIPIL1PDGFRA revolutionized treatment and outcome for patients, as the presence of the FIPIL1-PDGFRA fusion correlates to an exquisite sensitivity to the tyrosine kinase inhibitor (TKI) Imatinib. ${ }^{[3]}$ Whilst well described in adults, pediatric hypereosinophilia is rare, with only four cases of FIP1L1-PDGFRA fusion in children reported. ${ }^{[4-7]}$ We report the fifth known case of pediatric FIP1L1-PDGFRA hypereosinophilia; the fourth with documented morphological and molecular remission to Imatinib.

\section{Case presentation}

Our patient was a 14-year-old male of Sri-Lankan origin, who presented with a 2-week history of loss of weight, shortness of breath on exertion, and frequent cough. Examination revealed hepato-splenomegaly and bilateral inguinal lymphadenopathy, with no identified focal neurology. A 1.5 cm lump was noted on his posterior occiput that was firm to palpate, non-tender and non-mobile. Ophthalmological examination was normal.

*Correspondence: Rachel K Conyers, FRACP, MBBS, PHD; Email: Rachel.conyers@ rch.org.au; Address: 50 Flemington Road, Parkville, Australia. 
Initial white cell count was $200 \times 10^{9} / \mathrm{L}$, with a predominance of eosinophils $\left(40 \%, 39.88 \times 10^{9} / \mathrm{L}\right)$. A chest X-ray demonstrated bilateral peri-bronchial thickening and pulmonary infiltrates. Echocardiogram showed no evidence of pulmonary hypertension and good biventricular function with a normal fractional shortening. Lumbar Puncture was normal.
Bone marrow aspirate and trephine revealed a markedly hypercellular medullary space with immature and mature myeloid cells including neutrophils and eosinophils (see Figure 1). The immunophenotypic features were consistent with an excess of eosinophils and precursors with a modest myeloblast excess $(6 \%)$ and evidence of monocytoid differentiation by flow cytometry.

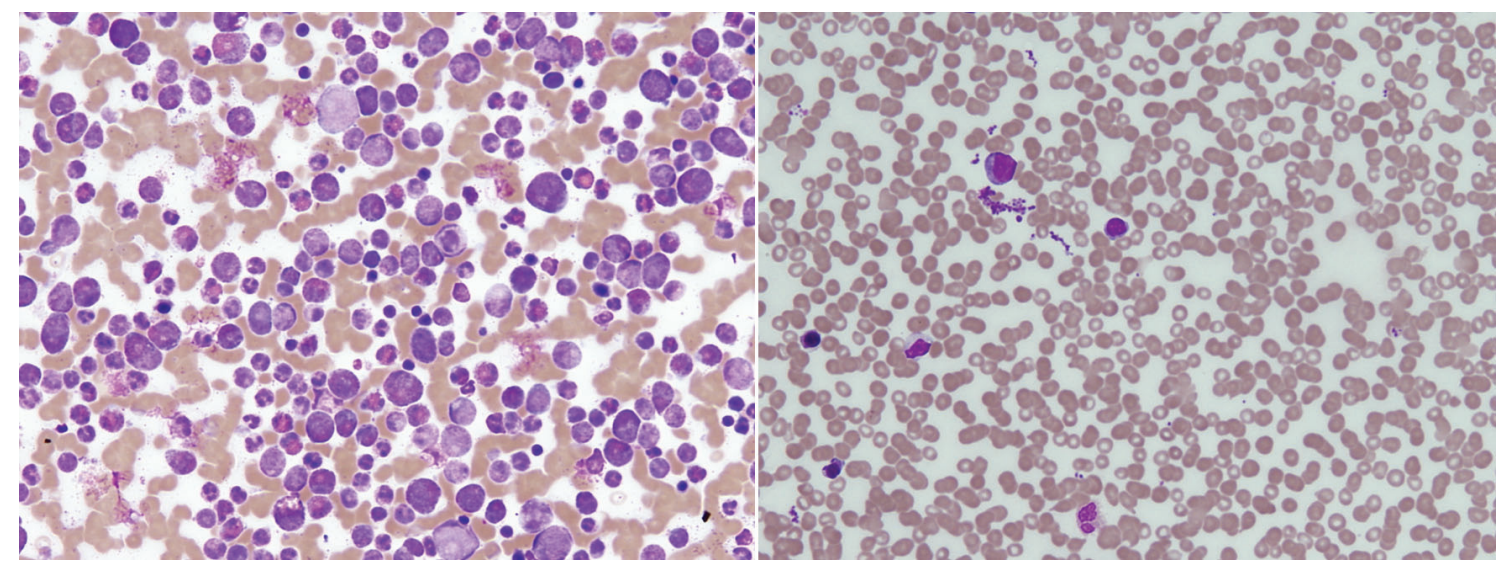

Figure 1. Bone marrow aspirate (BMA) smears at diagnosis and after 1 month of treatment with Imatinib Initial BMA at diagnosis demonstrates marked eosinophilia with all stages of eosinophilic differentiation. Subsequent BMA at Day 29 of treatment demonstrates no eosinophilia or excess of blasts, with no morphological evidence of disease. Picture credit to David Hughes.

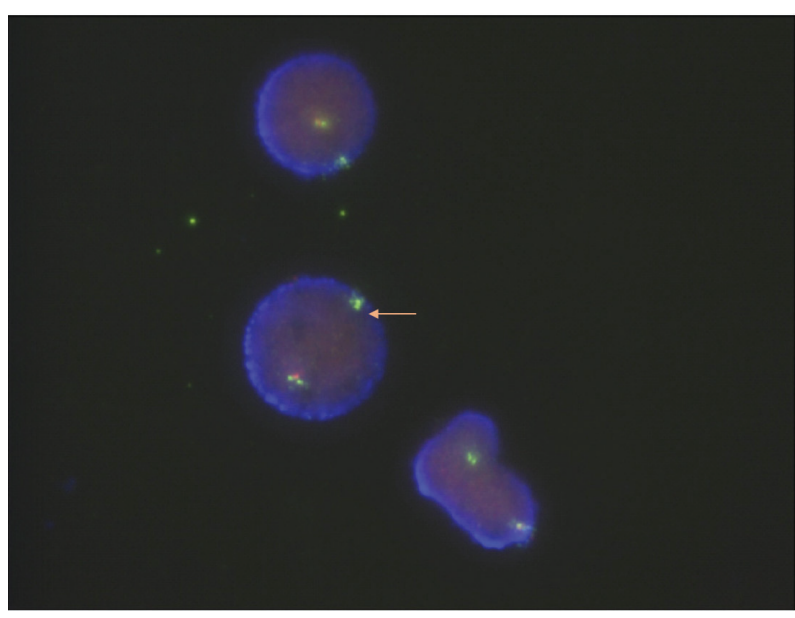

Figure 2. Fluorescence in situ hybridisation (FISH) analysis Triple-color FISH probes hybridizing to the region between the FIPIL1 and PDGFRA genes, incorporating the CHIC2

(cysteine-rich hydrophobic domain 2) gene. Interstitial deletion of CHIC2 (in red) occurs when the FIP1L1-PDGFRA fusion is present (arrow). Picture credit to Meghan Wall.

The patient commenced steroid and hydroxyurea whilst awaiting completion of molecular studies, but the peripheral blood eosinophilia and leucocytosis continued to rise. Fluorescent in-situ hybridisation (see Figure 2) revealed a FIP1L1-PDGFRA fusion, and the patient was commenced on Imatinib at a dose of $100 \mathrm{mg}$ daily. His response to Imatinib was brisk, with normalisation of his peripheral eosinophil count within 48 hours of commencing the TKI (see Figure 3). After a week of treatment with Imatinib, the patient had no further respiratory symptoms and the lump on his posterior occiput was no longer palpable.

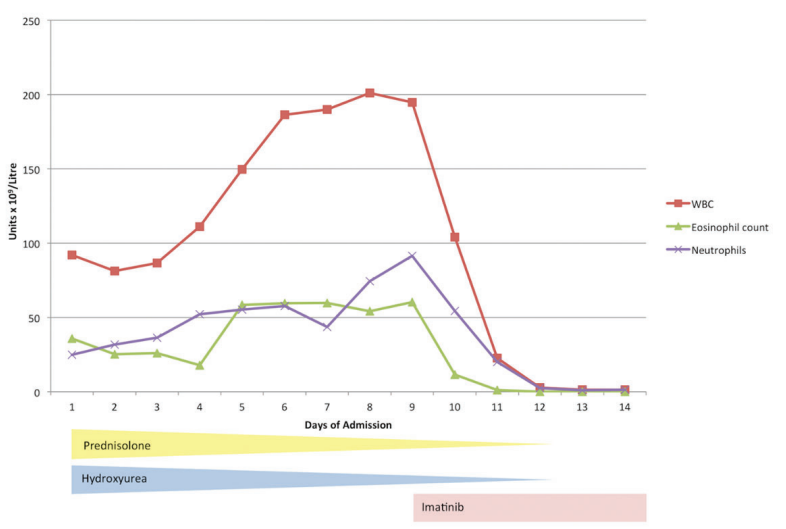

Figure 3. Timeline of treatment and hematological markers Dramatic improvement of white cell count, eosinophilia and neutrophilia after commencement of Imatinib. Abbreviations: WBC - white blood cell count.

Evidence of response to Imatinib was demonstrated clearly by Bone Marrow Aspirate (BMA) analysis, and Minimal Residual Disease (MRD) analysis - FIP1L1-PDGFRA identi- 
fied by Polymerase Chain Reaction (sensitivity down to $10^{-4}$ ). A BMA performed at Day 29 of treatment already demonstrated impressive response to Imatinib, with no eosinophils or blast cells identified (see Figure 1), and MRD identified by Polymerase Chain Reaction of $1 \times 10^{-3}$. His 6-month marrow showed MRD further reduced to $1 \times 10^{-4}$, and by 9 months of treatment, MRD was not detectable. His parents were keen to discuss the merits of a bone marrow transplant as a potentially curative option for his condition.

\section{Discussion}

The exquisite sensitivity to the TKI Imatinib appears to abrogate the immediate complications of hypereosinophilia in children (see Table 1), as it does in adults. However, this case report highlights several outstanding issues relating to treatment, particularly relevant to pediatric and young adult patients.

Table 1. Clinical characteristics of pediatric patients with clonal hypereosinophilia and molecular abnormalities of PDGFRA, PDGFRB or FGFR1

\begin{tabular}{|c|c|c|c|c|c|c|c|}
\hline Reference & Age & Sex & History at presentation & Clonal cytogenetic abnormality & $\begin{array}{l}\text { Eosinophil count } \\
\text { at diagnosis }\end{array}$ & Treatment & Outcome \\
\hline $\begin{array}{l}\text { Wang et al., } 2015 \\
\text { (current case) }\end{array}$ & 14 years & M & $\begin{array}{l}3 \text { months loss of weight, bone } \\
\text { pain, headaches, dizziness }\end{array}$ & FIP1L1-PDGFRA fusion & $60 \times 10^{9} / \mathrm{L}$ & $\begin{array}{l}\text { Steroids } \\
\text { Hydroxyurea } \\
\text { Imatinib } \\
100 \mathrm{mg} \text { daily }\end{array}$ & Recovery \\
\hline $\begin{array}{l}\text { Rives et al., } \\
2005^{[6]}\end{array}$ & 7 years & M & Pruritus and malaise. No HSM & FIP1L1-PDGFRA fusion & $6.1 \times 10^{9} / \mathrm{L}$ & Steroids & $\begin{array}{l}\text { Recovery, Imatinib } \\
\text { planned if relapse }\end{array}$ \\
\hline $\begin{array}{l}\text { Rapanotti et al., } \\
2010^{[7]}\end{array}$ & 16 years & M & $\begin{array}{l}\text { Restrictive cardiomyopathy, } \\
\text { lymphadenopathy. HSM present }\end{array}$ & FIP1L1-PDGFRA fusion & $5.3 \times 10^{9} / \mathrm{L}$ & $\begin{array}{l}\text { Imatinib } \\
400 \text { mg daily }\end{array}$ & Recovery \\
\hline $\begin{array}{l}\text { Rathe et al., } \\
2010^{[8]}\end{array}$ & 2 year & $\mathrm{F}$ & $\begin{array}{l}3 \text { days malaise, fatigue, loss of } \\
\text { appetite. No HSM }\end{array}$ & FIP1L1-PDGFRA fusion & $22.5 \times 10^{9} / \mathrm{L}$ & $\begin{array}{l}\text { Imatinib } \\
300 \mathrm{mg} / \mathrm{m}^{2} \text { daily }\end{array}$ & Recovery \\
\hline $\begin{array}{l}\text { Farruggia et al., } \\
2013^{[9]}\end{array}$ & 14 years & M & $\begin{array}{l}2 \text { months weight loss, pallor. } \\
\text { Left shoulder pain HSM present }\end{array}$ & FIP1L1-PDGFRA fusion & $49 \times 10^{9} / \mathrm{L}$ & Imatinib 200 mg daily & Recovery \\
\hline $\begin{array}{l}\text { Li et al., } \\
2010^{[10]}\end{array}$ & 8 years & M & $\begin{array}{l}\text { Cough, pallor and ulcers. HSM } \\
\text { present }\end{array}$ & TPM3-PDGFRB fusion & $\begin{array}{l}\text { N.A. } \\
\text { Bone Marrow } \\
45.5 \% \text { eosinophils }\end{array}$ & $\begin{array}{l}\text { Hydroxyurea } \\
\text { Interferon } \\
\text { Imatinib } 200 \mathrm{mg} / \mathrm{m}^{2} \text { daily }\end{array}$ & Recovery \\
\hline \multirow[t]{2}{*}{$\begin{array}{l}\text { Abraham et al., } \\
2012^{[11]}\end{array}$} & 3 months & M & Nodular lesions, HSM & TPM3-PDGFRB fusion & $5.6 \times 10^{9} / \mathrm{L}$ & $\begin{array}{l}\text { Hydroxyurea, Imatinib, } \\
340 \mathrm{mg} / \mathrm{m}^{2} \text { daily }\end{array}$ & Recovery \\
\hline & 4 years & M & $\begin{array}{l}\text { Failure to thrive, respiratory } \\
\text { infections, HSM }\end{array}$ & $\begin{array}{l}\text { FISH positive for } 5 \mathrm{q} 33 \\
\text { rearrangement involving PDGFRB }\end{array}$ & $3.9 \times 10^{9} / \mathrm{L}$ & $\begin{array}{l}\text { Imatinib, } \\
340 \mathrm{mg} / \mathrm{m}^{2} \text { daily }\end{array}$ & Recovery \\
\hline $\begin{array}{l}\text { Wilkinson et al., } \\
2003^{[51]}\end{array}$ & 11 months & $\mathrm{F}$ & Malaise, poor feeding. HSM & PDGRFB-PDE4DIP fusion & $\begin{array}{l}\text { WCC } 43.9 \times 10^{9} / \mathrm{L} \\
\text { with "marked } \\
\text { eosinophilia" }\end{array}$ & $\begin{array}{l}\text { Etoposide, Cytarabine, } \\
\text { Interferon, Imatinib }\end{array}$ & Recovery \\
\hline
\end{tabular}

Note. N.A., not available; HSM, Hepatosplenomegaly; WCC, white cell count; Bold and italicised font indicates treatment that achieved clinical remission.

Like Chronic Myeloid Leukaemia (CML), FIP1L1-PDGFRA hypereosinophilia patients face challenges regarding total length of required therapy. A group from the Mayo Clinic $^{[8]}$ recently reported upon 741 adult patients with hypereosinophilia, of which $3 \%$ (21) were FIP1L1-PDGFRA positive. 14 of the 21 patients treated with Imatinib all achieved a complete response. Of these 14,4 patients attempted to discontinue therapy but all relapsed. ${ }^{[11]}$ Several other studies have also reported small numbers of patients who relapsed following Imatinib discontinuation. ${ }^{[12,13]}$ These findings suggest that the use of TKI does not completely eradicate the clone, and that the use of TKI should be life-long.

Given that pediatric patients may require Imatinib long-term, the issue of possible Imatinib resistance becomes more relevant. To date, there are no reported pediatric cases of Imatinib resistance in patients with FIP1L1-PDGFRA. Imatinib resistance in adult patients with FIP1L1-PDGFR positive disease is low, occurring most frequently in patients developing blast crisis. A 2005 case report of a 67-year-old male patient with FIP1L1-PDGFRA positive hypereosinophilia reported that Imatinib resistance occurred 6 months into treatment, and cor- related with blast crisis. The T6741 mutation present showed a change of nucleotide 2417 of PDGFRA from cytosine to thymine, ${ }^{[14]}$ and has been described in three other reported cases of advanced disease, including blast crisis. ${ }^{[15-17]}$ Therefore, although few reported cases of resistance exist, what is clear is that in the face of resistance, disease factors (i.e. blast crisis) contribute to poor therapeutic options.

The optimal dose of Imatinib that maintains remission is unclear. Helbig et al. ${ }^{[18]}$ reported upon 6 patients positive for FIP1L1-PDGFRA initially treated with Imatinib 100-400 mg daily, until they achieved complete haematological remission (CHR). Subsequently they were dose decreased, till most were maintained on a single weekly dose of Imatinib of 100 mg-200 mg weekly. A similar dose reduction method was also adopted by the French Eosinophil Network series, who achieved complete molecular response in $95 \%$ of patients at a starting daily dose of $165 \mathrm{mg}$, then tapered Imatinib to a maintenance dose of $58 \mathrm{mg}$ daily. ${ }^{[19]}$ The limited studies to date suggest that in certain circumstances Imatinib can be dose reduced, provided MRD can be easily monitored. 
There are very few case reports in the literature that analyse the efficacy of bone marrow transplant in eradicating the FIP1L1-PDGFRA transcript. Halaburda et al. ${ }^{[20]}$ report a 29year-old patient who was transplanted for hypereosinophilia, in whom the FIPIL1-PDGFRA transcript was retrospectively shown to be positive in the sample at diagnosis. The patient received a matched sibling donor transplant using a myeloablative regime, and three years post-transplant remains well, in a molecular remission for the FIPIL1-PDGFRA fusion transcript.

This case highlights the importance of ongoing molecular target research in this new area of target therapy. The exquisite sensitivity to the TKI Imatinib appears to abrogate the immediate complications of hypereosinophilia in children. Though the incidence of Imatinib resistance in this disease is low in adults, it appears the use of Imatinib needs to be life-long; as yet, the long-term prognosis of these children is uncertain. Given the scant case reports for bone marrow transplant in FIPIL1-PDGFRA hypereosinophilic disease, it would appear that in pediatric or young adult patients, matched sibling transplants are only to be explored in cases that are refractory to Imatinib. Parents requesting transplantation should have individual cases presented to hospital Ethics committees, as this request would stand outside of current recommendations for this condition.

\section{CONFlicts OF InTEREST Disclosure}

The authors have declared no conflicts of interest.

\section{REFERENCES}

[1] Chusid MJ, Dale DC, West BC, et al. The hypereosinophilic syndrome: analysis of fourteen cases with review of the literature. Medicine (Baltimore). 1975; 54(1): 1-27. http://dx.doi.org /10.1097/00005792-197501000-00001

[2] Podjasek JC, Butterfield JH. Mortality in hypereosinophilic syndrome: 19 years of experience at Mayo Clinic with a review of the literature. Leuk Res. 2013; 37(4): 392-5. PMid:23332454 http://dx.doi.org/10.1016/j.leukres.2012.12.016

[3] Cools J, DeAngelo DJ, Gotlib J, et al. A tyrosine kinase created by fusion of the PDGFRA and FIP1L1 genes as a therapeutic target of imatinib in idiopathic hypereosinophilic syndrome. N Engl J Med. 2003; 348(13): 1201-14. PMid:12660384 http://dx.doi.org/1 $0.1056 /$ NEJMoa025217

[4] Rives S, Alcorta I, Toll T, et al. Idiopathic hypereosinophilic syndrome in children: report of a 7-year-old boy with FIP1L1PDGFRA rearrangement. J Pediatr Hematol Oncol. 2005; 27(12): 663-5. PMid:16344672 http://dx.doi.org/10.1097/01.mph. 0000193467.06938 .77

[5] Rapanotti MC, Caruso R, Ammatuna E, et al. Molecular characterization of paediatric idiopathic hypereosinophilia. Br J Haematol. 2010 151(5): 440-6. PMid:20955401 http://dx.doi.org/10.1111/j $.1365-2141.2010 .08394 . \mathrm{x}$

[6] Rathe M, Kristensen TK, Moller MB, et al. Myeloid neoplasm with prominent eosinophilia and PDGFRA rearrangement treated with imatinib mesylate. Pediatr Blood Cancer. 2010; 55(4): 730-2. PMid:20589620 http://dx.doi.org/10.1002/pbc. 22655

[7] Farruggia P, D’Angelo P, Acquaviva A, et al. Hypereosinophilic syndrome in childhood: clinical and molecular features of two cases. Pediatr Hematol Oncol. 2009; 26(3): 129-35. PMid:19382034 http://dx.doi.org/10.1080/08880010902773024

[8] Abraham S, Salama M, Hancock J, et al. Congenital and childhood myeloproliferative disorders with eosinophilia responsive to imatinib. Pediatr Blood Cancer. 2012; 59(5): 928-9. PMid:22488677 http://dx.doi.org/10.1002/pbc. 24148

[9] Li Z, Yang R, Zhao J, et al. Molecular diagnosis and targeted therapy of a pediatric chronic eosinophilic leukemia patient carrying TPM3-PDGFRB fusion. Pediatr Blood Cancer. 2011; 56(3): 463-6. PMid:21072821 http://dx.doi.org/10.1002/pbc. 22800
[10] Wilkinson K, Velloso ER, Lopes LF, et al. Cloning of the $\mathrm{t}(1 ; 5)(\mathrm{q} 23 ; \mathrm{q} 33)$ in a myeloproliferative disorder associated with eosinophilia: involvement of PDGFRB and response to imatinib. Blood. 2003; 102(12): 4187-90. PMid:12907457 http://dx.doi . org/10.1182/blood-2003-04-1150

[11] Pardanani A, Ketterling RP, Li CY, et al. FIP1L1-PDGFRA in eosinophilic disorders: prevalence in routine clinical practice, longterm experience with imatinib therapy, and a critical review of the literature. Leuk Res. 2006; 30(8): 965-70. PMid:16406016 http://dx.doi.org/10.1016/j.leukres.2005.11.011

[12] Jovanovic JV, Score J, Waghorn K, et al. Low-dose imatinib mesylate leads to rapid induction of major molecular responses and achievement of complete molecular remission in FIP1L1-PDGFRApositive chronic eosinophilic leukemia. Blood. 2007; 109(11): 463540. PMid:17299092 http://dx.doi.org/10.1182/blood-200 6-10-050054

[13] Baccarani M, Cilloni D, Rondoni M, et al. The efficacy of imatinib mesylate in patients with FIP1L1-PDGFRalpha-positive hypereosinophilic syndrome. Results of a multicenter prospective study. Haematologica. 2007; 92(9): 1173-9. PMid:17666373 http: //dx.doi.org/10.3324/haematol.11420

[14] von Bubnoff N, Sandherr M, Schlimok G, et al. Myeloid blast crisis evolving during imatinib treatment of an FIP1L1-PDGFR alpha-positive chronic myeloproliferative disease with prominent eosinophilia. Leukemia. 2005; 19(2): 286-7. PMid:15618966 http: //dx.doi.org/10.1038/sj.leu.2403600

[15] Ohnishi H, Kandabashi K, Maeda Y, et al. Watanabe, Chronic eosinophilic leukaemia with FIP1L1-PDGFRA fusion and T6741 mutation that evolved from Langerhans cell histiocytosis with eosinophilia after chemotherapy. Br J Haematol. 2006; 134(5): 5479. PMid:16856885 http://dx.doi.org/10.1111/j.1365-214 1.2006.06221.x

[16] Griffin JH, Leung J, Bruner RJ, et al. Discovery of a fusion kinase in EOL-1 cells and idiopathic hypereosinophilic syndrome. Proc Natl Acad Sci USA. 2003; 100(13): 7830-5. PMid:12808148 http://dx.doi.org/10.1073/pnas.0932698100

[17] Lierman E, Michaux L, Beullens E, et al. FIP1L1-PDGFRalpha D842V, a novel panresistant mutant, emerging after treatment of FIP1L1-PDGFRalpha T674I eosinophilic leukemia with single agent sorafenib. Leukemia. 2009; 23(5): 845-51. PMid:19212337 http: //dx.doi.org/10.1038/leu.2009.2 
[18] Helbig G, Stella-Holowiecka B, Majewski M, et al. A single weekly dose of imatinib is sufficient to induce and maintain remission of chronic eosinophilic leukaemia in FIP1L1-PDGFRA-expressing patients. Br J Haematol. 2008; 141(2): 200-4. PMid:18307562 http://dx.doi.org/10.1111/j.1365-2141.2008.07033.x

[19] Legrand F, Renneville A, Macintyre E, et al. The Spectrum of FIP1L1PDGFRA-Associated Chronic Eosinophilic Leukemia: New Insights
Based on a Survey of 44 Cases. Medicine (Baltimore). 2013.

[20] Halaburda K, Prejzner W, Szatkowski D, et al. Allogeneic bone marrow transplantation for hypereosinophilic syndrome: long-term follow-up with eradication of FIP1L1-PDGFRA fusion transcript. Bone Marrow Transplant. 2006; 38(4): 319-20. PMid:16819435 http://dx.doi.org/10.1038/sj.bmt.1705437 